\title{
Continuous positive air pressure (CPAP) should be used in all COVID-19 patients when the first and mild respiratory
} symptoms commence

\author{
Calixto Machado ${ }^{*}$, Phillip A DeFina², Yanín Machado ${ }^{1}$, Mauricio Chinchilla ${ }^{1}$, Elena Cuspineda ${ }^{1}$ and Yazmina Machado ${ }^{1}$ \\ ${ }^{1}$ Institute of Neurology and Neurosurgery, Havana, Cuba \\ ${ }^{2} \mathrm{CEO}$ of the International Brain Research Foundation, Cuba
}

\begin{abstract}
The most awful complication COVID-19 is hypoxemia due to respiratory failure. The mechanisms of lung damage and hypoxemia in COVID-19 include ventilation/ perfusion mismatch, loss of hypoxic vasoconstriction and increased coagulopathy. Hence, it is of particular attention that acute lung injury, hypoxemia, systemic inflammatory response syndrome, acute respiratory distress syndrome (ARDS) occurs after SARS-CoV-2 infection. Cytokine storm in COVID-19 patients is centrally involved in the aggravation of symptoms and disease development, and denotes a key factor contributing to ARDS and mortality. Indeed, there is a close relationship between lung damage, hypoxemia and the cytokine storm. Other important issue is to consider the possible presence of happy of silent hypoxemia, which is described in patients with pronounced arterial hypoxemia who don't express a sense of dyspnea. Moreover, pulse oximetry (PO) should be interpreted with caution, because due to left-sided shifting of the oxyhemoglobin dissociation curve during hypocapnia periods, PO might measure a normal oxygen saturation in spite of very low $\mathrm{PaO} 2$. Continuous positive air pressure (CPAP) is nowadays the preferred method of non-invasive ventilation (NIV) management of COVID-19 patients, has significant and helpful role in Covid-19 management, mainly if it is used in an early phase of the disease, because it may prevent clinical deterioration and reduce the need for invasive ventilation at all. We strongly recommend to early use CPAP in all Covid-19 patient who present the first mild respiratory symptoms, such as cough, or light tachypnea and hyperpnea, etc., when they are still outside the ICUs, i.e. in regular wards or at patient's homes. This method would prevent periods of hypopnea and hypoxia which can stimulate the synthesis of ACE in lung endothelial cells, leading to cytokine storm, which can cause ARDS, multi-organ failure, and death.
\end{abstract}

\section{Introduction}

One of the gravest complications of SARS-CoV-2 infection is the development of an atypical upper respiratory tract pneumonia that enforces a major challenge to clinicians in terms of disease management [1]. A substantial proportion of patients who are admitted to intensive care units (UCIs) worsen in a short period of time, leakproof clinical states, and die from acute respiratory distress syndrome (ARDS) [2-10].

The most awful complication COVID 19 is hypoxemia due to respiratory failure. The mechanisms of lung damage and hypoxemia in COVID 19 include ventilation/perfusion mismatch, loss of hypoxic vasoconstriction and increased coagulopathy. Hence, it is of particular attention that acute lung injury, hypoxemia, systemic inflammatory response syndrome (SIRS), and ARDS occur after SARS-CoV-2 infection [9,10,11-14].

An abnormal and uncontrolled production of cytokines has been observed in critically ill patients with COVID-19 pneumonia. The subsequent uncontrolled cytokine storm in COVID-19 patients is centrally involved in the aggravation of symptoms and disease development, and denotes a key factor contributing to ARDS and mortality [15-21]. Indeed, there is a close inter-relationship between of lung damage, hypoxemia and the cytokine storm [11,22-30]. According to the current WHO guidance, supportive therapy remains the most significant management strategy for this disease, including supplemental oxygen therapy, conservative fluid management and empiric antimicrobial application. Furthermore, new treatment protocols need to be established in order to control the prolonged and progressive hypoxia of COVID-19 patients [31].
The treatment for severe respiratory failure in Covid-19 patients have included early intubation and invasive ventilation, as this was deemed preferable to be more effective than Non-Invasive Ventilation (NIV). Nevertheless, NIV may have a more significant and helpful role than firstly thought, mainly if it is used in an early phase of the disease. NIV avoids the need for sedation, allows easier communication with patient, and requires less intensive nursing care [32-35].

\section{Hypoxia, cytokine storm and inflammation}

The SARS-CoV-2 virus binds and infects the cells via utilizing angiotensin converting enzyme 2 (ACE-2) as a receptor, which is widely found in tissues of the organism. It has been suggested that increased levels of ACE-2 were positively associated with COVID- 19 infection. There are two types of ACE (ACE-1 and ACE-2) acting oppositely in pulmonary endothelium; ACE-2 functions as a vasodepressor whereas ACE-1 functions as a vasoconstrictor. Under physiological conditions, there is a dynamic equilibrium between ACE-1 and ACE-2. Though, in conditions of hypoxemia like in COVID-19 infection, ACE-1 is

*Correspondence to: Calixto Machado, Institute of Neurology and Neurosurgery, Neurophysiology 29 y D, Vedado, La Habana 10400, Cuba, Email: braind@ infomed.sld.cu

Key words: covid-19; SARS-CoV-2; cytokine storm; acute respiratory distress syndrome (ARDS); non-invasive ventilation; CPAP

Received: September 09, 2020; Accepted: September 22, 2020; Published: September 29, 2020 
upregulated by the hypoxia-inducible factor-1 (HIF-1); meanwhile the expression of ACE-2 is noticeably reduced. Subsequently, both hypoxemia and related ACE-2 upregulation may deteriorate clinical outcomes in COVID-19 [11,36-45].

The immune system has an exquisite mechanism capable of responding to various pathogens. Normal anti-viral immune response necessitates the activation of the inflammatory pathways of the immune system. Nevertheless, aberrant or exaggerated response of the host's immune system can cause severe disease if remains uncontrolled [46-50].

The cytokine storm is an activation cascade of auto-amplifying cytokine production due to unregulated host immune response to dissimilar triggers. The term cytokine storm calls up bright images of an immune system gone awry and an inflammatory response burst out of control. The cytokine storm is a systemic inflammatory response to infections and drugs leading to excessive activation of immune cells and generating pro-inflammatory cytokines. Cytokines are an indispensable part of the inflammatory process. Cytokines are produced by several immune cells including the innate macrophages, dendritic cells, natural killer cells and the adaptive $\mathrm{T}$ and $\mathrm{B}$ lymphocytes [16,51-58].

Due to rapid endothelial dysfunction in the lungs, microthrombi may occur by activation of the coagulation system, resulting in drastic changes in blood rheology and causing organ failure due to hypoperfusion or misperfusion. In Covid-19, the aberrant release of pro-inflammatory factors leads to lung epithelial and endothelial cell apoptosis which damages the lung microvascular and alveolar epithelial cell barrier, leading to vascular leakage, alveolar edema and hypoxia [59-69]. Cytokine mediated injury of lung endothelial and epithelial cells may damage the integrity of blood/air barrier, thus promoting vascular permeability in addition to alveolar edema, infiltration by inflammatory cells (i.e. neutrophils and macrophages) and hypoxia. Certain kinds of cytokines trigger cell death, causing that a lot of tissue can die. In COVID-19, that tissue is mostly in the lung. As the tissue breaks down, the walls of the lungs' tiny air sacs become leaky and fill with fluid, causing pneumonia and starving the blood of oxygen $[24,68,70,71]$. These phenomena also lead to lack of oxygen supply in the tissues or organs due to hypoperfusion of blood. Moreover, proinflammatory cytokines suppress the oxygen utilization of mitochondria, resulting in a change of metabolic pathway from oxidative phosphorylation to glycolysis, thus causing cells to change their mode of metabolism to glycolytic or anaerobic. Increased oxygen demands of infiltrated immune cells, reduced supply of metabolic substrates by blood clots and compression of blood vessels, and atelectasis of lung contribute to tissue hypoxia during inflammation, inducing hypoxemia, and triggering more proinflammatory cytokines [72-82].

Tissue hypoxia during inflammation is not just a simple passerby process, but can significantly affect the development or attenuation of inflammation by causing the regulation of hypoxia-dependent gene expression. Several studies analyzing cytokine profiles from COVID-19 patients have suggested that the cytokine storm correlated directly with lung injury, hypoxemia, multi-organ failure, and unfavorable prognosis of severe COVID-19 [28,83-88].The exposure to hypoxia promotes several transcription factors, which plays a central role in stimulating the proinflammatory cytokines TNF- $\alpha$ and IL-6. Hypoxia is a microenvironmental feature of chronically inflamed tissues which can impact upon the progression of inflammation in a number of ways. HIF and NF- $\kappa \mathrm{B}$ are two hypoxia- responsive transcription factors which, as well as controlling independent cohorts of adaptive and inflammatory genes, demonstrate a high degree of interdependence. Central to the activation of both the HIF and NF- $\kappa B$ pathways in hypoxia appear to be the oxygen- sensing hydroxylases. Certainly, the study of transcriptionally regulated tissue adaptation to hypoxia necessitates further research to help control hypoxia-induced inflammation and multiple organ failure [28,57,89-100]. Inflammatory cytokines. Cytokines are an indispensable part of the inflammatory process. Cytokines are produced by several immune cells including the innate macrophages, dendritic cells, natural killer cells and the adaptive $\mathrm{T}$ and $\mathrm{B}$ lymphocytes [16,51-58].

\section{Happy or silent hypoxemia}

Other very important issue to consider is the possible presence of "happy or silent hypoxemia". One of the aspects perplexing clinicians who take care of COVID-19 patients with pronounced arterial hypoxemia, yet without proportional signs of respiratory distress, with even deceiving cyanosis, is that they don't even express a sense of dyspnea. This phenomenon is referred as 'happy or silent hypoxemia". For clinicians the presence of happy or silent hypoxemia in Covid-19 patients, in spite of pronounced arterial hypoxemia, can erroneously lead to the conclusion that the patient is not in a critical condition. Those cases can quickly leapfrog clinical evolution stages and suffer ARDS, with concomitant cardiorespiratory arrest and death $[59,101,105]$.

\section{Pulse oximetry: changes in oxyhemoglobin dissociation curve}

Pulse oximetry which measures oxygen saturation $(\mathrm{SpO} 2)$ is very often used to detect hypoxemia. Nevertheless, $\mathrm{SpO} 2$ should be carefully interpreted in COVID-19. The sigmoid shaped oxyhemoglobin dissociation curve seems to shift to the left, due to induced respiratory alkalosis (drop in PaCO2) because of hypoxemia-driven tachypnea and hyperpnea. During hypocapnic periods, the affinity of hemoglobin for oxygen and thus oxygen saturation rises for a specified degree of $\mathrm{PaO} 2$, explaining why $\mathrm{SpO} 2$ can be well-preserved in the face of a profoundly low $\mathrm{PaO} 2$. In high altitude hypoxemia, hypocapnia significantly changes the oxygen-hemoglobin dissociation curve and recovers blood oxygen saturation. The alveolar gas equation also predicts that hyperventilation and the resulting drop in the alveolar partial pressure of $\mathrm{CO} 2$ produces an increment in the alveolar partial pressure of oxygen and finally lead to a raise in SpO2 [103,106].

\section{Invasive or non-invasive ventilation in Covid-19 patients}

Over the past decade, the use of noninvasive ventilation (NIV) in the setting of acute exacerbations of chronic obstructive pulmonary disease has gained popularity $[32,107,108]$. The treatment for severe respiratory failure in Covid-19 patients have included early intubation and invasive ventilation, as this was deemed preferable to be more effective than Non-Invasive Ventilation (NIV). Nevertheless, evolving evidence has shown that NIV may have a more significant and helpful role than it was firstly considered. NIV avoids the need for sedation, allows easier communication with patient, and requires less intensive nursing care [32-35].

There are three types of NIV: High Flow Nasal Oxygen (HFNO), Continuous Positive Aire Pressure (CPAP) and BiPAP (Bi-Level Positive Airway Pressure) [32]. 


\section{High Flow Nasal Oxygen (HFNO)}

HFNO therapy through a nasal cannula is a technique whereby heated and humidified oxygen is delivered to the nose at high flow rates. These high flow rates generate low level of positive pressure in the upper airways, and the fraction of inspired oxygen (FIO2) can be attuned by varying the fraction of oxygen in the driving gas. The high flow rates may also reduce physiological dead space by flushing expired $\mathrm{CO} 2$ from the upper airway, a process that possibly explains the observed decrement in the process of breathing. In patients with acute respiratory failure of various origins, high flow oxygen has been shown to result in better comfort and oxygenation than standard oxygen therapy delivered through a face mask [35,109]. Nonetheless, the use of HFVO remains controversial in suspected and confirmed severe cases of COVID-19 disease. As a result, currently in the UK, the national guidance does not recommend HFNO in COVID-19 because for the lack of evidence of efficacy, the high oxygen usage, and risk of infection spread $[8,14,35,110]$.

\section{Bilevel positive airway pressure (BiPAP)}

BiPAP is commonly used in the care of patients with chronic respiratory disease, so it may be useful in COVID-19 patients. In COVID-19, BiPAP may have a clinical use to improve the work of breathing. However, it carries a risk that inappropriate settings may allow the patient to take an excessively large tidal volume causing baro and volutrauma. BiPAP allows for a high driving pressure coupled with a low driving pressure. Prior to commencing BiPAP, the patient must be assessed for a pneumothorax, ideally by a chest X-Ray or ultrasound. Due to the need for chest auscultation for COVID-19 patients, is not recommended as it increases the risk of transmission to the healthcare professional $[8,111,112]$.

\section{Continuous Positive Airway Pressure (CPAP)}

CPAP is nowadays the preferred form of NIV in the management of COVID-19 patients. With improved and commercial available CPAP equipment, there is now growing evidence that it may be of benefit to patients in the disease process, avoiding hypoxia, and then may preventing deterioration and reducing the need for invasive ventilation at all [113-116]. CPAP is usually commenced at a higher level than normal intrinsic pressure around $5 \mathrm{~cm} \mathrm{H} 2 \mathrm{O}$. For most patients with ARDS, it is secondary to conditions which either collapse the alveolar or widen the gap between the alveolar and the blood vessels that surround them thereby reducing gaseous exchange. The application of Positive End Expiratory Pressure (PEEP) assists in maintaining the patient's airway pressure prevents alveolar collapse, in turn increasing lung volumes and distends them to reduce the distance between the alveolar and the blood vessels to improve gaseous exchange. In severe COVID-19, initial CPAP setting have been suggested $10 \mathrm{~cm} \mathrm{H} 2 \mathrm{O}$ and $60 \%$ oxygen [14,110,112,116-122].

\section{Conclusion}

We strongly recommend to early use CPAP in all Covid-19 patient who present the first mild respiratory symptoms, such as cough, or light tachypnea and hyperpnea, etc., when they are still outside the ICUs, i.e. in regular wards or at patient's homes. This method would prevent periods of hypopnea and hypoxia which can stimulate the synthesis of ACE in lung endothelial cells, finally leading to cytokine storm, which can cause ARDS and multi-organ failure $[9,14,110,112,116,118]$.

\section{References}

1. De Virgiliis F, Di Giovanni S (2020) Lung innervation in the eye of a cytokine storm neuroimmune interactions and COVID-19. Nat Rev Neurol 16: 645-652.

2. Chen JY, Qiao K, Liu F, Wu B, Xu X, et al. (2020) Lung transplantation as therapeutic option in acute respiratory distress syndrome for COVID-19-related pulmonary fibrosis. Chin Med J 133: 1390-1396. [Crossref]

3. Li YC, Bai WZ, Hashikawa T (2020) The neuroinvasive potential of SARS-CoV2 may play a role in the respiratory failure of COVID-19 patients. J Med Virol 25728. [Crossref]

4. Wu C, Chen X, Cai Y, Xia J, Zhou X, et al. (2020) Risk Factors Associated with Acute Respiratory Distress Syndrome and Death in Patients with Coronavirus Disease 2019 Pneumonia in Wuhan, China. JAMA Intern Med 180: 934-943. [Crossref]

5. Tang X, Du R, Wang R, Cao TZ, Guan LU et al. (2020) Comparison of Hospitalized Patients with Acute Respiratory Distress Syndrome Caused by COVID-19 and H1N1. Chest 158: 195-205. [Crossref]

6. De Maio A, Hightower LE (2020) COVID-19, acute respiratory distress syndrome (ARDS), and hyperbaric oxygen therapy (HBOT): what is the link? Cell Stress Chaperones. 25: 717-720. [Crossref]

7. Li Z, Liu T, Yang N, Yang N, Han D, Mi X, et al. (2020) Neurological manifestations of patients with COVID- 19: potential routes of SARS-CoV-2 neuroinvasion from the periphery to the brain. Front Med: 1-9. [Crossref]

8. Whittle JS, Pavlov I, Sacchetti AD, Atwood C, Rosenberg MS (2020) Respiratory support for adult patients with COVID-19. J Am Coll Emerg Physicians Open 1: 95101. [Crossref]

9. Machado C (2020) Severe Covid-19 cases: Is respiratory distress partially explained by central nervous system involvement? Medicc Rev 22: 38-41. [Crossref]

10. Machado C (2020) Reader response: Neurologists and COVID-19: A note on courage in a time of uncertainty. Neurol.

11. Wang X, Tu Y, Huang B, Li Y, Li Y, et al. (2020) Pulmonary vascular endothelial injury and acute pulmonary hypertension caused by COVID-19: the fundamental cause of refractory hypoxemia? Cardiovasc Diagn Ther 10: 892-897. [Crossref]

12. Schmauss M, Muller E, Schwamborn M, Giesa C, Ewig S (2020) ECMO Therapy in a Case of Severe ARDS Related to COVID-19. Pneumologie 74: 423-428. [Crossref]

13. Ottestad W, Seim M, Maehlen JO (2020) COVID-19 with silent hypoxemia. Tidsskr Nor Laegeforen 140: 7. [Crossref]

14. Czajkowska-Malinowska M, Kania A, Kuca PJ, Nasiłowski J, Skoczyński S, et al (2020) Treatment of acute respiratory failure in the course of COVID-19. Practical hints from the expert panel of the Assembly of Intensive Care and Rehabilitation of the Polish Respiratory Society. Adv Respir Med 88: 245-266. [Crossref]

15. Zhou T, Su TT, Mudianto T, Wang J (2020) Immune asynchrony in COVID-19 pathogenesis and potential immunotherapies. J Exp Med 217: e20200674.

16. Zhao M (2020) Cytokine storm and immunomodulatory therapy in COVID-19: Role of chloroquine and anti-IL-6 monoclonal antibodies. Int J Antimicrob Agents 55: 105982. [Crossref]

17. Zhang W, Zhao Y, Zhang F, Wang Q, Li T, et al. (2020) The use of anti-inflammatory drugs in the treatment of people with severe coronavirus disease 2019 (COVID-19): The Perspectives of clinical immunologists from China. Clin Immunol 214:108393. [Crossref]

18. Ye Q, Wang B, Mao J (2020) The pathogenesis and treatment of the 'Cytokine Storm' in COVID-19. J Infect 80: 607-613. [Crossref]

19. Yang R, Xiong Y, Ke H, Chen T, Gao S (2020) The role of methylprednisolone on preventing disease progression for hospitalized patients with severe COVID-19. Eur J Clin Invest e13412. [Crossref]

20. Veras FP, Pontelli MC, Silva CM, Toller-Kawahisa JE, De Lima M, et al. (2020) SARS-CoV-2-triggered neutrophil extracellular traps mediate COVID-19 pathology. J Exp Med 217: e20201129.

21. Van Eeden C, Khan L, Osman MS, Cohen Tervaert JW (2020) Natural killer cell dysfunction and its role in COVID-19. Int J Mol Sci 21: 6351. [Crossref]

22. Sigman SA, Mokmeli S, Monici M, Vetrici MA (2020) A 57-Year-Old African American Man with Severe COVID-19 Pneumonia Who Responded to Supportive Photobiomodulation Therapy (PBMT): First Use of PBMT in COVID-19. Am J Case Rep 21: e926771-e926779. [Crossref] 
23. Zeng Z, Xu L, Xie XY, Yan HL, Xie BJ, et al. (2020) Pulmonary Pathology of Early Phase COVID-19 Pneumonia in a Patient with a Benign Lung Lesion. Histopathology 77: 823-831. [Crossref]

24. Ackermann M, Verleden SE, Kuehnel M, Haverich A, Welte T, et al. (2020) Pulmonary Vascular Endothelialitis, Thrombosis, and Angiogenesis in Covid-19. N Engl J Med 383: 120-128. [Crossref]

25. Abbas S, Ahmad A, Lacasse A (2020) COVID-19 infection and its deadly cytokine storm in a young obese adult. J Community Hosp Intern Med Perspect 10: 295-298. [Crossref]

26. Chatterjee S, Sengupta T, Majumder S, Majumder R (2020) COVID-19: a probable role of the anticoagulant Protein S in managing COVID-19-associated coagulopathy. Aging 12:15954-15961. [Crossref]

27. Petrey AC, Qeadan F, Middleton EA, Pinchuk IV, Campbell RA, Beswick EJ (2020) Cytokine release syndrome in COVID-19: Innate immune, vascular, and platelet pathogenic factors differ in severity of disease and sex. J Leukoc Biol 1-12.

28. Del Vecchio L, Locatelli F (2020) Hypoxia response and acute lung and kidney injury: possible implications for therapy of COVID-19. Clin Kidney J 13: 494-499.

29. Mallis P, Michalopoulos E, Chatzistamatiou T, Stavropoulos-Giokas C (2020) Mesenchymal stromal cells as potential immunomodulatory players in severe acute respiratory distress syndrome induced by SARS-CoV-2 infection. World J Stem Cells 12: 731-751. [Crossref]

30. Afsar B, Kanbay M, Afsar RE (2020) Hypoxia inducible factor-1 protects against COVID- 19: A hypothesis. Med Hypotheses 143:109857. [Crossref]

31. Bajema KL, Oster AM, McGovern OL, Lindstrom S, Stenger MR, et al. (2020) Persons Evaluated for 2019 Novel Coronavirus - United States, January 2020. MMWR Morb Mortal Wkly Rep 69:166-170. [Crossref]

32. Alraddadi BM, Qushmaq I, Al-Hameed FM, Mandourah Y, Almekhlafi GA, et al. (2019) Noninvasive ventilation in critically ill patients with the Middle East respiratory syndrome. Influenza Other Respir Viruses 13: 382-390. [Crossref]

33. Qin C, Zhou L, Hu Z, Yang S, Zhang S, et al. (2020) Clinical Characteristics and Outcomes of COVID-19 Patients with a History of Stroke in Wuhan, China. Stroke 51:2219-2223. [Crossref]

34. Suen CM, Hui DSC, Memtsoudis SG, Chung F (2020) Obstructive Sleep Apnea, Obesity, and Noninvasive Ventilation: Considerations During the COVID-19 Pandemic. Anesth Analg 131:318-322. [Crossref]

35. Wang K, Zhao W, Li J, Shu W, Duan J (2020) The experience of high-flow nasal cannula in hospitalized patients with 2019 novel coronavirus-infected pneumonia in two hospitals of Chongqing, China. Ann Intensive Care 10: 37. [Crossref]

36. Yin XX, Zheng XR, Peng W, Wu ML, Mao XY (2020) Vascular Endothelial Growth Factor (VEGF) as a Vital Target for Brain Inflammation during the COVID-19 Outbreak. ACS Chem Neurosci 11:1704-1705. [Crossref]

37. Hussain M, Jabeen N, Raza F, Shabbir S, A Baig A, et al (2020) Structural variations in human ACE2 may influence its binding with SARS-CoV-2 spike protein. $J$ Med Virol 25832.[Crossref]

38. Guo J, Wei X, Li Q, Li L, Yang Z, et al. (2020) Single-cell RNA analysis on ACE2 expression provides insights into SARS-CoV-2 potential entry into the bloodstream and heart injury. J Cell Physiol 29802. [Crossref]

39. Singal CMS, Jaiswal P, Seth P (2020) SARS-CoV-2, More than a Respiratory Virus: Its Potential Role in Neuropathogenesis. ACS Chem Neurosci 11:1887-1899.

40. Luan J, Jin X, Lu Y, Zhang L (2020) SARS-CoV-2 spike protein favors ACE2 from Bovidae and Cricetidae. J Med Virol 25817. [Crossref]

41. Buzhdygan TP, DeOre BJ, Baldwin-Leclair A, McGary H, Razmpour R, et al. The SARS-CoV-2 spike protein alters barrier function in 2D static and 3D microfluidic in vitro models of the human blood-brain barrier. BioRxiv 32587958. [Crossref]

42. Lukassen S, Lorenz Chua R, Trefzer T, Kahn NC, Schneider MA, et al. (2020) SARS$\mathrm{CoV}-2$ receptor ACE2 and TMPRSS2 are primarily expressed in bronchial transient secretory cells. EMBO J 20105114. [Crossref]

43. Beacon TH, Su RC, Lakowski TM, Delcuve GP, Davie J (2020) SARS-CoV-2 multifaceted interaction with the human host. Part II: Innate immunity response, immunopathology, and epigenetics. IUBMB Life 2379. [Crossref]

44. Delcuve GP, Lakowski TM, Su RC, Beacon TH, Davie JR (2020) SARS-CoV-2 multifaceted interaction with human host. Part I: What we have learnt and done so far, and the still unknown realities. IUBMB Life 2380. [Crossref]
45. Verdecchia P, Cavallini C, Spanevello A, Angeli F (2020) The pivotal link between ACE2 deficiency and SARS-CoV-2 infection. Eur J Intern Med 76:14-20. [Crossref]

46. Baig AM (2020) Updates on What ACS Reported: Emerging Evidence of COVID-19 with Nervous System Involvement. ACS Chem Neurosci 11:1204-1205.

47. O'Connell P, Aldhamen YA (2020) Systemic innate and adaptive immune responses to SARS-CoV-2 as it relates to other coronaviruses. Hum Vaccin Immunother 1- 12. [Crossref]

48. Pilotto A, Odolini S, Masciocchi S, Comelli A, Volonghi I, et al. (2020) SteroidResponsive encephalitis in coronavirus disease 2019. Ann Neurol 88: 423-427. [Crossref]

49. Ali A, Kamjani MH, Kesselman MM (2020) The role of tocilizumab in cytokine storm and improving outcomes in COVID-19. Recent Pat Antiinfect Drug Discov 22155712 [Crossref]

50. Shibabaw T, Molla MD, Teferi B, Ayelign B (2020) Role of IFN and complements system: innate immunity in SARS-CoV-2. J Inflamm Res 13: 507-518. [Crossref]

51. Lozada-Requena I, Nunez Ponce C (2020) Rev Peru Med Exp Salud Publica. 37:312- 319.

52. Fara A, Mitrev Z, Rosalia RA, Assas BM (2020) Cytokine storm and COVID-19: a chronicle of pro-inflammatory cytokines. Open Biol 10: 200160. [Crossref]

53. Wang J, Jiang M, Chen X, Montaner LJ (2020) Cytokine storm and leukocyte changes in mild versus severe SARS-CoV-2 infection: Review of 3939 COVID-19 patients in China and emerging pathogenesis and therapy concepts. J Leukoc Biol 108:17-41. [Crossref]

54. Nemchand P, Tahir H, Mediwake R, Lee J (2020) Cytokine storm and use of anakinra in a patient with COVID-19. BMJ Case Rep 13: e237525.

55. Fiorino S, Gallo C, Zippi M, Sabbatani S, Manfredi R, et al. (2020) Cytokine storm in aged people with $\mathrm{CoV}-2$ : possible role of vitamins as therapy or preventive strategy. Aging Clin Exp Res 32: 2115-2131. [Crossref]

56. Ur A, Verma K (2020) Cytokine Storm in COVID19: A Neural Hypothesis. ACS Chem Neurosci 11:1868-1870. [Crossref]

57. Castelli V, Cimini A, Ferri C (2020) Cytokine Storm in COVID-19: "When You Come Out of the Storm, You Won't Be the Same Person Who Walked in". Front Immunol 11:2132. [Crossref]

58. Song P, Li W, Xie J, Hou Y, You C (2020) Cytokine Storm Induced by SARS-CoV-2. Clin Chim Acta 509: 280-287. [Crossref]

59. Tobin MJ, Laghi F, Jubran A (2020) Why COVID-19 Silent Hypoxemia Is Baffling to Physicians. Am J Respir Crit Care Med 202:356-360. [Crossref]

60. UR Anoop, Verma K (2020) Pulmonary Edema in COVID19-A Neural hypothesis ACS Chem Neurosci 15: 2048-2050. [Crossref]

61. Nunes Duarte-Neto A, de Almeida Monteiro RA, da Silva LFF, Malheiros D, De Oliveira E, et al. (2020) Pulmonary and systemic involvement of COVID-19 assessed by ultrasound-guided minimally invasive autopsy. Histopathology 14160. [Crossref]

62. Ranucci M, Ballotta A, Di Dedda U, Bayshnikova E, Dei Poli M, et al. (2020) The procoagulant pattern of patients with COVID-19 acute respiratory distress syndrome. $J$ Thromb Haemost 18: 1747-1751. [Crossref]

63. Chen L, Li X, Chen M, Feng Y, Xiong C (2020) The ACE2 expression in human heart indicates new potential mechanism of heart injury among patients infected with SARSCoV-2. Cardiovasc Res 116:1097-1100. [Crossref]

64. Marchetti M (2020) COVID-19-driven endothelial damage: complement, HIF-1, and ABL2 are potential pathways of damage and targets for cure. Ann Hematol 99:17011707. [Crossref]

65. Rambaldi A, Gritti G, Mico MC, Frigeni M, Borleri G, et al. (2020) Endothelial injury and thrombotic microangiopathy in COVID-19: Treatment with the lectin-pathway inhibitor narsoplimab. Immunobiology 152001.

66. Yalcin AD, Yalcin AN (2020) Future perspective: biologic agents in patients with severe COVID-19. Immunopharmacol Immunotoxicol 2020:1-7. [Crossref]

67. Booz GW, Altara R, Eid AH, Wehbe Z, Fares S, et al. (2020) Macrophage responses associated with COVID- 19: A pharmacological perspective. Eur J Pharmacol 887:173547. [Crossref]

68. Ciceri F, Beretta L, Scandroglio AM, Colombo S, Giovanni Landoni et al. (2020) Microvascular COVID-19 lung vessels obstructive thromboinflammatory syndrome (MicroCLOTS): an atypical acute respiratory distress syndrome working hypothesis. Crit Care Resusc. 22: 95-97. [Crossref] 
69. Vinayagam S, Sattu K (2020) SARS-CoV-2 and coagulation disorders in different organs. Life Sci 260:118431. [Crossref]

70. Bhagat R, Prajapati B, Narwal S, Agnihotri N, Yogita K, et al. (2018) Zika virus E protein alters the properties of human fetal neural stem cells by modulating microRNA circuitry. Cell Death Differ 25:1837-1854.

71. Campana P, Parisi V, Leosco D, Bencivenga D, Ragione DF, et al. (2020) Dendritic cells and SARS-CoV-2 Infection: Still an unclarified connection. Cells 9: 2046. [Crossref]

72. Thompson E, Cascino K, Ordonez A, Zhou W, Vaghasia A, et al. (2020) Mitochondria induced $\mathrm{T}$ cell apoptosis and aberrant myeloid metabolic programs define distinct immune cell subsets during acute and recovered SARS-CoV-2 infection. medRxiv. [Crossref]

73. Khalil H, Abd ElHady A, Elawdan KA, Mohamed D, Mohamed DD, et al. (2020) The Mechanical Autophagy as a Part of Cellular Immunity; Facts and Features in Treating the Medical Disorders. Immunol Invest :1-24.

74. Lopez-Collazo E, Avendano-Ortiz J, Martin-Quiros A, Aguirre LA (2020) Immune Response and COVID-19: A mirror image of Sepsis. Int J Biol Sci 16: 2479-2489. [Crossref]

75. Chen J, Jin Y, Yang Y, Wu Z, Wu G (2020) Epithelial Dysfunction in Lung Diseases: Effects of Amino Acids and Potential Mechanisms. Adv Exp Med Biol 1265:57-70. [Crossref]

76. Burel-Vandenbos F, Cardot-Leccia N, Passeron T (2020) Apoptosis and pericyte loss in alveolar capillaries in COVID-19 infection: choice of markers matters. Author's reply. Intensive Care Med 46:1967-1968. [Crossref]

77. Taghiloo S, Aliyali M, Abedi S, Mehravaran H, Sharifpour A, et al.(2020) Apoptosis and immunophenotyping of peripheral blood lymphocytes in Iranian COVID-19 patients: Clinical and laboratory characteristics. J Med Virol 26505. [Crossref]

78. Karunakaran S, Diwakar L, Saeed U, Agarwal V, Ramakrishnan S, et al. (2007) Activation of apoptosis signal regulating kinase 1 (ASK1) and translocation of death-associated protein, Daxx, in substantia nigra pars compacta in a mouse mode of Parkinson's disease: protection by alpha- lipoic acid. FASEB J 21: 2226-2236. [Crossref]

79. Lara PC, Macias-Verde D, Burgos-Burgos J (2020) Age-induced NLRP3 Inflammasome Over-activation Increases Lethality of SARS-CoV-2 Pneumonia in Elderly Patients. Aging Dis 11:756-762. [Crossref]

80. Prasun P (2020) Letter to the Editor: COVID-19, Mitochondria, and Interferon. $J$ Interferon Cytokine Res 40: 466-467. [Crossref]

81. Saleh J, Peyssonnaux C, Singh KK, Edeas M (2020) Mitochondria and microbiota dysfunction in COVID-19 pathogenesis. Mitochondrion 54:1-7.

82. Gatti P, Ilamathi HS, Todkar K, Germain M (2020) Mitochondria Targeted Vira Replication and Survival Strategies-Prospective on SARS-CoV-2. Front Pharmacol 11: 578599. [Crossref]

83. Shenoy S (2020) Coronavirus (Covid-19) sepsis: revisiting mitochondrial dysfunction in pathogenesis, aging, inflammation, and mortality. Inflamm Res 69:1077-1085. [Crossref]

84. Appelberg S, Gupta S, Svensson Akusjarvi S, Ambikan AT, Mikaeloff F, et al. (2020) Dysregulation in Akt/mTOR/HIF-1 signaling identified by proteo-transcriptomics of SARS-CoV-2 infected cells. Emerg Microbes Infect 9: 1748-1760. [Crossref]

85. Young BE, Fong SW, Chan YH, Minn Mak T, Ang LW, et al. (2020) Effects of a major deletion in the SARS- CoV-2 genome on the severity of infection and the inflammatory response: an observational cohort study. Lancet 396: 603-611.

86. Samoilov MO, Semenov DG, Yarantsev NG, Evdokimov SA (1984) Sensitivity of "silent" and background-active neurons of the cat cortex to anoxia. Neurosci Behav Physiol 14: 307-312. [Crossref]

87. Falcone C, Caracciolo M, Correale P, Macheda S, Vadalà EG, et al. (2020) Can adenosine fight COVID-19 acute respiratory distress syndrome? J Clin Med 9: 3045. [Crossref]

88. Potus F, Mai V, Lebret M, Malenfant S, Gagnon EB, et al. (2020) Novel insights on the pulmonary vascular consequences of COVID-19. Am J Physiol Lung Cell Mol Physiol 319: L277-L288. [Crossref]

89. Loganathan S, Kuppusamy M, Wankhar W, Gurugubelli KR, MahadevappA VH, et al. (2020) Angiotensin-converting enzyme 2 (ACE2): COVID 19 gate way to multiple organ failure syndromes. Respir Physiol Neurobiol 283:103548. [Crossref]

90. Huang H, Zhang M, Chen C, Zhang H, Wei Y, et al. (2020) Clinical characteristics of COVID-19 in patients with preexisting ILD: A retrospective study in a single center in Wuhan, China. J Med Virol 26174. [Crossref]
91. Lung T, Kazatchkine MD, Risch L, Risch M, Nydegger UE (2020) A consideration of convalescent plasma and plasma derivatives in the care of Severely ill patients with COVID-19. Transfus Apher Sci 102936. [Crossref]

92. Kempuraj D, Selvakumar GP, Ahmed ME, Thangavel R, Dhaliwal AS, et al. (2020) COVID-19, Mast Cells, Cytokine Storm, Psychological Stress, and Neuroinflammation. Neuroscientist 941476

93. Kang S, Tanaka T, Inoue H, Ono C, Hashimoto S, et al. (2020) IL-6 trans-signaling induces plasminogen activator inhibitor-1 from vascular endothelial cells in cytokine release syndrome. Proc Natl Acad Sci U S A 117: 22351-22356. [Crossref]

94. Yinda CK, Port JR, Bushmaker T, Owusu IO, Avanzato VA, et al. (2020) K18-hACE2 mice develop respiratory disease resembling severe COVID-19. BioRxiv 246314 [Crossref]

95. Copaescu A, Smibert O, Gibson A, Phillips EJ, Trubiano JA (2020) The role of IL-6 and other mediators in the cytokine storm associated with SARS-CoV-2 infection. $J$ Allergy Clin Immunol 146: 518-534. [Crossref]

96. Vanderheiden A, Ralfs P, Chirkova T, Upadhyay AA, Zimmerman MG, et al. (2020) Type I and type III interferons restrict SARS-CoV-2 infection of human airway epithelial cultures. J Virol 94: 985-1020.

97. Letson HL, Granfeldt A, Jensen TH, Mattson TH, Dobson GP (2020) Adenosine, lidocaine, and magnesium support a high flow, hypotensive, vasodilatory state with improved oxygen delivery and cerebral protection in a pig model of noncompressible hemorrhage. J Surg Res 253:127-138. [Crossref]

98. Evans CE (2019) Hypoxia and HIF activation as a possible link between sepsis and thrombosis. Thromb J 17:16. [Crossref]

99. Han F, Wu G, Han S, Li Z, Jia Y et al. (2020) Hypoxia-inducible factor prolylhydroxylase inhibitor roxadustat (FG-4592) alleviates sepsis-induced acute lung injury. Respir Physiol Neurobiol 281:103506.

100. Xiao X, Ye M, Xu Y, Jiang C (2020) Role of hypoxia-inducible factor in immunometabolism of sepsis. Zhonghua Wei Zhong Bing Ji Jiu Yi Xue 32: 382-384. [Crossref]

101. U RA, Verma K (2020) Happy Hypoxemia in COVID-19-A Neural Hypothesis. ACS Chem Neurosci 11: 1865-1867. [Crossref]

102. Gonzalez-Duarte A, Norcliffe-Kaufmann L (2020) Is 'happy hypoxia' in COVID-19 a disorder of autonomic interoception? A hypothesis. Clin Auton Res 30: 331-333. [Crossref]

103. Dhont S, Derom E, Van Braeckel E, Depuydt P, Lambrecht BN (2020) The pathophysiology of 'happy' hypoxemia in COVID-19. Respir Res 21:198.

104. Chan GC, Lam B, Yap DY, Ip MS, Lai KN, et al. (2016) Proteinuria is associated with sleep apnea in chronic kidney disease. Nephrol Dial Transplant 31: 772-779. [Crossref]

105. Tobin MJ, Laghi F, Jubran A (2020) Reply to: On happy hypoxia and on sadly ignored acute vascular distress syndrome in COVID-19 patients. Am J Respir Crit Care Med 202007. [Crossref]

106. Liu W, Li H (2020) COVID-19:Attacks the 1-Beta chain of hemoglobin and captures the porphyrin to inhibit human heme metabolism. ChemRxiv 11938173.

107. Pirzada AR, Aleissi SA, Almeneessier AS, BaHammam AS (2020) Management of aerosol during noninvasive ventilation for patients with sleep-disordered breathing: important messages during the COVID-19 pandemic. Sleep Vigil 1-6. [Crossref]

108. Sartini C, Tresoldi M, Scarpellini P, Tettamanti A, Carcò F, et al. (2020) Respiratory parameters in patients with covid-19 after using noninvasive ventilation in the prone position outside the intensive care unit. JAMA 323: 2338-2340. [Crossref]

109. Akbarian-Rad Z, Mohammadi A, Khafri S, Ahmadpour-Kacho M, Zahed-Pasha Y et al. (2020) Comparison of heated humidified high flow nasal cannula and nasa continuous positive airway pressure after surfactant administration in preterm neonates with respiratory distress syndrome. Clin Respir J 14: 13191.

110. Perkins GD, Couper K, Connolly B, Baillie JK, Bradley JM, et al. (2020) RECOVERY- Respiratory Support: Respiratory Strategies for patients with suspected or proven COVID-19 respiratory failure; Continuous Positive Airway Pressure, High-flow Nasal Oxygen, and standard care: A structured summary of a study protocol for a randomized controlled trial. Trials 21: 687. [Crossref]

111. Chiner E, Canovas C, Molina V, Sancho-Chust JN, Vañes S, et al. (2020) Home respiratory polygraphy is useful in the diagnosis of childhood obstructive sleep apnea syndrome. J Clin Med 9: 2067. [Crossref]

112. Rali AS, Howard C, Miller R, Morgan CK, Mejia D, et al. (2020) Helmet CPAP revisited in COVID-19 pneumonia: A case series. Can J Respir Ther 56: 32-34. [Crossref] 
113. Stais P, Salloum O, Kuhle D, Fisteag S, Kambartel K, et al. (2020) 48-Year-Old Triathlete with Severe COVID-19 Pneumonia: Successful and Safe Treatment with Oxygen and CPAP. Pneumologie 74: 417-422. [Crossref]

114. Knights H, Mayor N, Millar K, Cox M, Bunova E, et al. (2020) Characteristics and outcomes of patients with COVID-19 at a district general hospital in Surrey, UK Clin Med (Lond) 20: e148-e153. [Crossref]

115. Pons-Odena M, Valls A, Grifols J, Farre R, Cambra Lasosa FJ, et al. (2020) COVID19 and respiratory support devices. Paediatr Respir Rev 35: 61-63.

116. Barker J, Oyefeso O, Koeckerling D, Mudalige NL, Pan D (2020) COVID-19: community CPAP and NIV should be stopped unless medically necessary to support life. Thorax 75: 367. [Crossref]

117. Baker JG, Sovani M (2020) Case for continuing community NIV and CPAP during the COVID-19 epidemic. Thorax 75: 368. [Crossref]
118. Mwenge GB, Rodenstein D (2020) CPAP Added to Oxygen Administration Avoid Intubation in Acute Respiratory Distress in COVID-19 Pneumonia. Case Report. $S N$ Compr Clin Med 1-4. [Crossref]

119. Thorpy M, Figuera-Losada M, Ahmed I, Monderera R, Petrisko M, et al. (2020) Management of sleep apnea in New York City during the COVID-19 pandemic. Sleep Med 74: 86-90.

120. Pirzada A, Awadh AA, Aleissi SA, Almeneessier AS, BaHammam AS (2020) Reopening Sleep Medicine Services in the Conundrum of an Ongoing COVID-19 Pandemic: A Global View. Sleep Vigil :1-8. [Crossref]

121. Nakano H, Kadowaki M, Furukawa T, Yoshida M (2020) Rise in nocturnal respiratory rate during CPAP may be an early sign of COVID-19 in patients with obstructive sleep apnea. J Clin Sleep Med 16: 1811-1813. [Crossref]

122. Bastier PL, Aisenberg N, Durand F, Lestang P, Abedipour D, et al. (2020) Treatment of sleep apnea by ENT specialists during the COVID-19 pandemic. Eur Ann Otorhinolaryngol Head Neck Dis 137: 319-321. [Crossref]

Copyright: (C2020 Machado C. This is an open-access article distributed under the terms of the Creative Commons Attribution License, which permits unrestricted use, distribution, and reproduction in any medium, provided the original author and source are credited. 